\title{
Territoires de l'étrange dans la littérature irlandaise au xxe siècle
}

Mark Fitzpatrick

\section{(2) OpenEdition \\ 1 Journals}

\section{Electronic version}

URL: http://journals.openedition.org/etudesirlandaises/2233

DOI: 10.4000 /etudesirlandaises.2233

ISSN: 2259-8863

\section{Publisher}

Presses universitaires de Caen

\section{Printed version}

Date of publication: 30 June 2011

Number of pages: $189-190$

ISBN: 978-2-7535-1348-8

ISSN: 0183-973X

\section{Electronic reference}

Mark Fitzpatrick, "Territoires de l'étrange dans la littérature irlandaise au xxe siècle », Études irlandaises [Online], 36-1 | 2011, Online since 30 June 2011, connection on 21 September 2020. URL : http:// journals.openedition.org/etudesirlandaises/2233; DOI : https://doi.org/10.4000/etudesirlandaises. 2233

This text was automatically generated on 21 September 2020.

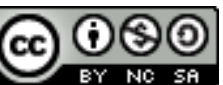

Études irlandaises est mise à disposition selon les termes de la Licence Creative Commons Attribution - Pas d'Utilisation Commerciale - Partage dans les Mêmes Conditions 4.0 International. 


\title{
Territoires de l'étrange dans la littérature irlandaise au xxe siècle
}

\author{
Mark Fitzpatrick
}

\section{REFERENCES}

Gaïd Girard (dir.), Territoires de l'étrange dans la littérature irlandaise au $\mathrm{XX}^{e}$ siècle, Rennes, Presses Universitaires de Rennes, 2009, 275 p., ISBN 978-2-7535-0842-2, $18 €$

1 Gaïd Girard's collection of essays, the proceedings of a symposium on $20^{\text {th }}$ century Irish literature's strange lands, could not have been more appropriate reading material while visiting Ireland in December 2010, after the almost-unprecedented general snowfall. The white shroud undifferentiating, defamiliarising the landscape, provoked the unquieting anxiety of the blank page, erasing the signs of the present, to leave us in what Chris Morash's essay, closing the volume, calls "the continuous past".

2 Indeed, this persistence - or, as in Maryvonne Boisseau's illuminating contribution, this rémanance - this afterglow of an essential strangeness in Irish literature, often most associated with the $19^{\text {th }}$ century gothic, throughout the $20^{\text {th }}$ century's various forms and transformations, is at the heart of the territory that this volume attempts to map. If, as Girard's introduction points out, we are to agree with Terry Eagleton's assessment of Ireland as the "monstrous unconscious of the metropolitan society", and position ourselves “critically" (with Paul Muldoon's "critically positioned figure", interestingly translated by Girard as a "figure en déséquilibre", thus spatialising an idea, as so many of these texts proceed to do), then we must take account of many subtle boundaries, intersecting "territoires", and many-layered anachronologies in the long history of a young nation.

3 Questions of genre, and the spectral, indeterminate limits between them, inform many contributions, with Todorov's Introduction à la literature fantastique a key text, deployed perhaps to greatest effect by Morash, who articulates Todorov's approach with that of Max Weber's concept of disenchantment, and Victor Sage, whose contribution on 
"McGahern's Inverted Uncanny", where he also brings into play the Burkean Sublime as the Uncanny's mysterious double, is a stern test of the solidity of the lead of one's underlining pencil.

4 Claude Fierobe's magisterial opening essay surveys the territory to be explored, with a plotting of Irish $20^{\text {th }}$ century fiction's "Territoires d'inquiétude", and we are then treated to an unsettling trip through haunted history, the Big House in Trevor and Banville, ironic disenchantment and poetic re-enchantment in Wilde's, Bowen's, Ciaran Carson's ghosts, the power of words, and of silence, in AE, Flann O'Brien, and Beckett, to return to the worrying strangeness in the real, and the disquiet of a stranger politics in the volume's final section.

5 The idea of the Uncanny receives the expected attention, with some treatments of it more subtle than others; Magali Falco's exploration of its presence in Banville's Birchwood suffers from the playful, arch series of self-conscious variations that the novel itself plays on notions of the Gothic, the carnival, the (Un)Heimlich. 